City was only slightly affected. At the same time, the volcano near Colima erupted, setting fire to forests. These fires further threatened Colima.

\section{Recent Earthquakes recorded at Kew}

Foun large earthquakes have been recorded at Kew in the period March 23-April 13. The first was received at $22 \mathrm{~h} .41 \mathrm{~m}$. $17 \mathrm{~s}$. G.M.T. on March 28 and may have been from an epicentre $19,000 \mathrm{~km}$. distant, though the initial mo"ements were confused by microseisms. The second was at $10 \mathrm{~h} .52 \mathrm{~m} .19 \mathrm{~s}$. on April 1, probably from an epicentre $7,870 \mathrm{~km}$. distant, while the third, at $15 \mathrm{~h} .34 \mathrm{~m}$. $31 \mathrm{~s}$. G.M.T. on April 3, had its epicentre 9,180 km. away. This latter had a particularly prominent wave on all three components at $15 \mathrm{~h} .33 \cdot 5 \mathrm{~m}$. G.M.T., which may have been eSSS. An earthquake giving a full suite of pulses had iP dilatational at $23 \mathrm{~h} .40 \mathrm{~m}$. $27 \mathrm{~s}$. G.M.T. on April 7 and did not cease recording until $3 \mathrm{~h} .20 \mathrm{~m}$. G.M.T. on April 8. It probably had its epicentre $7,920 \mathrm{~km}$. distant from Kew, though all calculated epicentral distances are tentative.

\section{Canadian Polar Year Expeditions}

THE first volume of a work which describes the observations carried out by the Canadian Polar Year Expeditions, 1932-33, is largely statistical; but there is a general introduction by Dr. J. Patterson, the director of the Canadian Meteorological Service, and notes on the instruments at the Expeditions' four stations-Cape Hope's Advance, Chesterfield Inlet, Coppermine and Meanook, together with maps and photographs (Dominion of Canada: Department of Transport, Air Services Branch, Division of Meteorological Services of Canada. Canadian Polar Year Expeditions, 1932-33, Meteorology : Cape Hope's Advance, Chesterfield Inlet, Coppermine, Meanook. Vol. 1. Pp. xvi $+443+46$ plates. Ottawa: King's Printer, 1940). Meanook (Alberta) is a permanent magnetic station-the nearest to the north magnetic pole-the other three stations were temporarily set up for this undertaking. The statistical matter which, as has already been mentioned, occupies a very large proportion of the volume, consists mainly of hourly values of atmospheric pressure, temperature, humidity, precipitation, sunshine and wind velocity, to which are added full particulars of the upper winds revealed by numerous observations with pilot balloons, and notes on optical phenomena. The period covered-August 1932September 1933--is long enough to illustrate the inhospitable climate of these regions, with frequent gales and strong winds, and a long and severe winter. The complete absence of trees, and even of bushes, worthy of the name, at the more northerly stations needs no other explanation.

At Coppermine, pilot balloon observations were supplemented by seventy-four soundings with kites carrying Marvin meteorographs lent by the U.S. Weather Bureau, but the results do not appear to be given in this volume. The same station was supplied with several Patterson flashing-lamp balloon meteoro- graphs. This is a very light form of meteorograph which indicates pressure and temperature by the lighting up of a string of electric bulbs suspended by a silk cord beneath the balloon, an observation consisting of the identification of the bulbs shining at a particular moment. Graphs of temperature observa. tions up to $2 \mathrm{~km}$. obtained in this way in March 1933 are given, all of which show at least one inversion or disappearance of lapse of temperature with height, below $1 \mathrm{~km}$. At Meanook, the most southerly of the four stations $\left(54^{\circ} 37^{\prime} \mathrm{N}\right.$.), noctilucent clouds of the kind described by Størmer were observed on the night of July $20-21,1933$, at a height exceeding $55 \mathrm{~km}$. This appears to be the first occasion on which such clouds have been noted in America.

\section{A Plastic for Thermal Insulation}

IN the electrical industry cellulose acetate is widely used in both sheet form and as mouldings. A multilayer insulating material, made from cellulose acetate, and known as 'Isoflex', is described in the Electrician of March 7. Isoflex is manufactured from cellulose acetate film and in structure is not unlike corrugated cardboard used for packing purposes, with about five layers to each inch of thickness. It has a thermal conductivity of 0.32 B.TH.U. per hour per sq. ft. per in. thickness per $1^{\circ} \mathrm{F}$. difference of temperature, so that its insulation properties compare very favourably with slab-cork $(0.25$ B.TH.U.), glass-fibre $(0 \cdot 28$ B.TH.U.) and wood fibre board $(0.38$ B.TH.U.). Its volume weight of $0.75 \mathrm{lb}$. per cu. ft. works out at about onetenth that of slab-cork. This makes it of considerable interest in connexion with thermal insulation during transport.

Isoflex is non-porous and non-absorbent, with the result that its thermal insulation is not impaired by the deposition of moisture in the material. Its construction in the tubular form allows free draining of condensed moisture. From the constructional point of view it is very easy to handle, as it can readily be cut by a knife. It will withstand wear and tear, and it does not disintegrate under the severe vibration of a railway coach; it is inert to salt water, thus making it suitable for marine work. It will not ignite or burn by itself, and therefore its installation does not result in an increase in the fire risk. How. ever, it melts at about $175^{\circ} \mathrm{C}$. and it is not suitable for heat insulation at temperatures which exceed $75^{\circ} \mathrm{C}$. Isoflex is available in two types of slab. One type, known as the standard slab, is 24 in. square and is rigid; the other, the flexible slab, measures 23 in. $\times 20$ in. By cutting one or other of these slabs, and by using a combination of them, any desired shape can be built up without difficulty.

\section{Electric Supply in Churches}

THE eighth report of the Central Council for the Care of Churches includes a timely memorandum for the guidance of parochial authorities about to install new lighting apparatus, and a series of regulations to be observed by contractors. In a preface to the regulations is a statement that the work must comply with the regulations of the Institution of 